\title{
Print media reportage of agricultural biotechnology in the Philippines: a decade's (2000-2009) analysis of news coverage and framing
}

\author{
Mariechel J. Navarro, Jenny A. Panopio, Donna Bae Malayang, Noel Amano Jr.
}

\begin{abstract}
This article presents key results of a ten-year study of media coverage of agricultural biotechnology in the Philippines, the only country in Asia to date to approve a biotech food/feed crop (Bt corn) for commercialization. The top three national English newspapers - Manila Bulletin, Philippine Daily Inquirer, and Philippine Star were analyzed to determine patterns of media attention measured by coverage peaks, tone, source of news, keywords, and media frames used. Biotechnology news was generally positive but not high in the media agenda. News coverage was marked by occasional peaks brought about by drama and controversial events which triggered attention but not long enough to sustain interest. The study provides a glimpse into the role of mass media in a developing country context. It shows how a complex and contentious topic is integrated into the mainstream of news reporting, and eventually evolves from an emotional discourse to one that allows informed decision making.
\end{abstract}

\section{Background}

Agricultural biotechnology is one of several strategies that complement conventional technology in addressing problems of food, feed, and energy, and environmental degradation. Developing countries like the Philippines considers biotechnology as an enabling tool for the country to attain global competitiveness and in achieving the national vision of economic growth and social equity. ${ }^{1}$

The Philippines is the first and only Asian country to approve the planting of Bt corn, a genetically modified food/feed crop. Some 250,000 small resource-poor farmers are estimated to be growing biotech maize and the country is ranked $11^{\text {th }}$ worldwide in terms of area planted to biotech crops. ${ }^{2}$ Asia is expected to determine the direction of the biotech debate as the stakes are high in the continent where a huge market in seeds and crops are expected.

Media plays a significant role in defining what the general public understands about the technology, and at the same time provides the environment by which public opinion is formed about what is often perceived as controversial if not contentious issue. Media sets the agenda and tone for what the public will deem interesting or important. News media in particular serves an important source of informal learning and contributes to how citizens reach judgments about the complexities of science and technology or policy debates. A low information public tends to rely heavily on a 'convenience sample' of media's interpretation of an issue. ${ }^{3}$

Framing involves organizing and structuring information so that it is socially shared and provides meaning to reality, i.e. issue or event. This involves deliberate identification of an aspect of a perceived reality, and giving interpretation and evaluation of that reality. ${ }^{4}$ Hence, it is unlikely that enough critical attention to any given set of issues is given to stimulate public thinking without a certain level of media activity. ${ }^{5}$

Bias in reporting events depends on unfolding events and scientific and risk management controversies. News stories offer the public definitions of social reality where an occurrence is turned into a newsworthy event, a newsworthy event into a story, which is then communicated to the public. ${ }^{6}$ Controversy carries news value and creates a peak in media coverage. Biotechnology needs to be looked at from an issue-cycle perspective where attention to the topic is not constant but at varying levels due to triggering events. Mass media coverage thus has the potential to strongly influence public opinion particularly during critical peak coverage. ${ }^{7}$ 
Europe and North America have studied extensively ${ }^{8,9,10,11}$ about biotechnology, media, and public opinion. There is a dearth however, of similar studies in developing countries such as the Philippines. This is validated in a meta-analysis of studies in the media's coverage of science which shows a research bias towards Europe (54.7\%) and North America (40\%). Asia accounted for only $0.4 \%{ }^{12}$ A synthesis of researches on public perceptions of biotechnology in the country and from 13 reports of quantitative and qualitative studies concluded that Filipinos' knowledge and experience with biotechnology ranged from substantial to nil but had a common high regard for and expectations of science including biotechnology. ${ }^{13}$ Filipinos consider mass media as the most frequently used source of information on biotechnology. ${ }^{14,15}$

A study ${ }^{16}$ on elite Asian newspaper coverage of agricultural biotechnology covering 1998-2002 sought to compare three newspapers in China, Philippines and Hongkong. Modest coverage on the technology was noted in the three countries with events meeting the requirements of novelty and drama. A media monitoring survey of 46 national newspapers in five Asian countries: India, Malaysia, Philippines, South Korea and Vietnam showed sustained coverage from 2002 to 2003 with articles generally neutral to positive, supportive of government and private sector initiatives, and focused on the social/cultural or economic angle of the technology. ${ }^{17}$ These studies however did not take an in-depth analysis of how media coverage evolved over a significant time period.

\section{Purpose and objectives}

This study investigated ten years (2000-2009) of media coverage on agricultural biotechnology in the Philippines by the top three circulated national English newspapers: Manila Bulletin, Philippine Daily Inquirer, and the Philippine Star. This period is prime for media analysis as it was during this time that GM crops were first introduced and eventually commercialized in the country.

The research sought to describe and analyze the nature and content of published agri-biotech articles in terms of published articles, tone of article, source of article, and category of article. It also aimed to identify prominent media frames and devices that writers used to define or explain biotechnology.

Specifically, the study attempted to answer four research questions:

1. How have the top three daily newspapers in the Philippines covered the topic of agricultural biotechnology during the ten-year period?

2. What general tone did the three newspapers use in their coverage of agricultural biotechnology?

3. What are the news sources of these three newspapers?

4. What are the prominent media frames used by writers in defining agricultural biotechnology?

The study is a contribution to understanding the biotech debate through 'symbolic confrontation' or reportage in the print media and how it might affect public opinion in a developing country context. With very few literature on this topic in the Philippines and Asia, this study is a significant contribution to science communication in general and biotech communication in particular.

\section{Methods/procedures}

The top three daily English newspapers in the Philippines based on circulation figures were identified as sources for the articles: Manila Bulletin, Philippine Daily Inquirer, and Philippine Star. All three newspapers have been in the business since 2000, the start of this study. A Nielsen Media Research ${ }^{18}$ in 2007 showed that the Philippine Daily Inquirer was the choice of 53\% of those who said they had read a broadsheet with 1.3 million readers. Manila Bulletin ranked second with 47\% and the Philippine Star at third with $42 \%$. For this present study, biotechnology was limited to modern crop biotechnology, or the use of modern techniques such as recombinant DNA technology, specifically cloning, genetic engineering, and molecular markers to improve agricultural productivity.

Articles were collected in three modes to assure completeness of entries: online database search in newspaper libraries using the following keywords; biotechnology, genetically modified, and genetically engineered; manual search of actual articles; and microfilm file search at academic libraries. Longitudinal studies are difficult to conduct in the Philippines due to lack of full-text databases such as LexisNexis commonly used in Western countries. Only one newspaper had a complete online search system, hence 
the use of multiple collection procedures. The total population of articles was collected resulting in 1,355 articles during the 10-year period.

Each individual article identified as a study unit was subjected to quantitative content analysis. A coding template was used to summarize the following information: title of article, newspaper, date of publication, page published, article type (news, feature, opinion), tone (positive, neutral, negative), and source of information. Through textual analysis, full text of each article was coded by prominent framing category, and keywords used. The frames as shown in Table 1 were adapted from earlier studies on framing. ${ }^{19,20,21}$ Independent sample t-tests were used to identify significant mean differences among the frames.

Biotech event milestones were compared in terms of peak coverage with major political events. This analysis enabled a more holistic approach into understanding the prominence and saliency of biotech news vis a vis other important news during the same time period.

\begin{tabular}{|l|l|}
\hline \multicolumn{1}{|c|}{ FRAME } & \multicolumn{1}{c|}{ CONTEXT } \\
\hline $\begin{array}{l}\text { Social Progress/Economic } \\
\text { Development }\end{array}$ & $\begin{array}{l}\text { Improving quality of life and harmony with nature; } \\
\text { Local/global competitiveness }\end{array}$ \\
\hline Morality/Ethics & $\begin{array}{l}\text { Identification with values that determine what is right or } \\
\text { wrong, acceptable or unacceptable }\end{array}$ \\
\hline Scientific Validity & $\begin{array}{l}\text { A matter of expert understanding what is known versus } \\
\text { unknown; calls on the authority of sound science or peer- } \\
\text { review }\end{array}$ \\
\hline Public Accountability/Governance & $\begin{array}{l}\text { Research in the public good or responsible use or abuse of } \\
\text { science in decision-making }\end{array}$ \\
\hline New Research & Discovery announcement, new scientific application \\
\hline Conflict/Strategy & Who's ahead or behind in debate; battle of personalities \\
\hline Public Engagement & $\begin{array}{l}\text { Focus on poll results, reporting of public opinion statistics, } \\
\text { public sentiments, personal testimony of farmer or consumer }\end{array}$ \\
\hline Others & Context not included in frames above \\
\hline
\end{tabular}

Table 1. A framing typology for biotechnology.

\section{Results}

The print media in the Philippines, although described as the 'freest in Asia', is still regulated to some extent by the government. This incongruent setting merges with high media interest in both politics and entertainment (hence, news reportage morphing into entertainment). Ninety percent of 645 publications in 2004 were newspapers and tabloids. The National Capital Region (Metro Manila) remains to be the center of print media operations of which the Manila Bulletin (MB), Philippine Star (PS), and Philippine Daily Inquirer (PDI) are the dominant papers in terms of circulation. ${ }^{22}$

Overall Media Coverage, 2000-2009. The top three newspapers published a total of 1,355 articles on modern crop biotechnology during a ten year period or a yearly average of 136 articles (Figure 1). MB published 52\%, with the PDI accounting for $24 \%$ and PS with $24 \%$. MB has a dedicated section for agriculture and a business features page, PDI has a science and technology page, while PS has agriculture and science and technology sections. MB published more than $50 \%$ of the total articles combined and it consistently had the most number of articles on a year-to-year basis except for 2007. Nevertheless, MB managed to substantially write about biotech such that in 2005 for example, it released 110 articles versus only 32 by PS and 10 by PDI (Figure 2 ). 


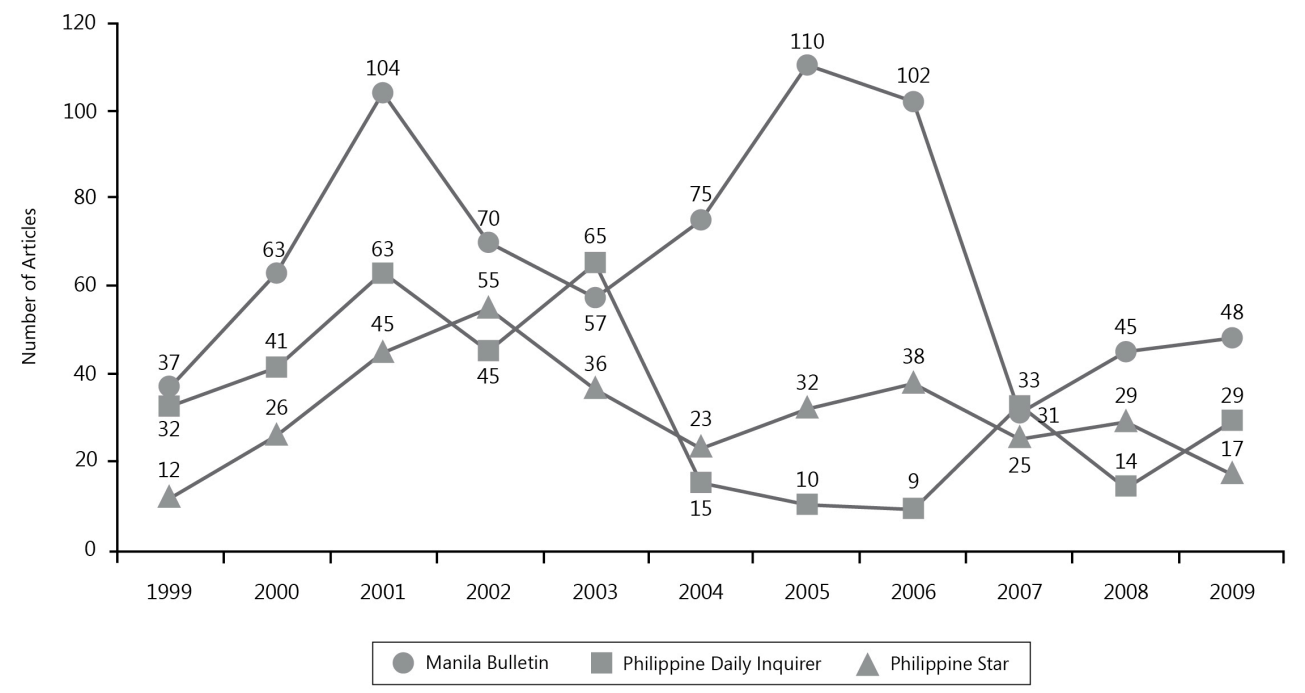

Figure 1. Comparative number of articles published yearly by the top three Philippine newspapers, 2000-2009. Note: 1999 data provided to allow comparison.

An analysis of journalists that wrote the articles showed a core of science writers that consistently write about biotechnology. MB and PS has at least two to four writers who have followed the biotech scene from the research phase to succeeding events that eventually saw farmers planting biotech corn on their farms. The most prolific writer from the MB wrote 119 articles on biotechnology between 2001 to 2009 , or an average of 15 articles per year. A columnist of MB discussed biotech in his column 20 times from 2004-2006. Second most productive writer was from the PS, contributing 81 articles or a monthly average of 8 articles for a ten year period. Both writers have been given awards for biotech writing and science writing, respectively during the last few years. The PDI had a pool of writers who wrote about biotechnology but unlike PS and MB did not average as many articles during the period of study.

Figure 2 shows media coverage of biotech events. In the early years of media coverage, biotechnology was a relatively new topic and writers used information from foreign news. In the absence of a local product, media coverage was on how the technology could "feed the world population" and at the same time "threaten the planet." Golden rice which was then in the limelight in Europe and the U.S. was the product being hailed as "super rice for Asia", and "miracle rice to solve vitamin A deficiency of $24 \mathrm{M}$ children worldwide." In 2001, most of the articles discussed the field testing of genetically modified corn which signaled serious local efforts to join the biotech bandwagon. A significant event which increased interest in the topic was the issuance of support for biotech from the Philippine president. Hence, peak coverage was from 2001 to 2003, the period prior to approval of commercial planting of Bt corn, approval of planting on farmers' fields, and start of commercialization of a first food/feed biotech crop in an Asian country. Environmental groups such as Greenpeace and Ecological Society of the Philippines took interest which also coincided with issues regarding genetic modification (GM) issues in Europe and the U.S. Media coverage was also high 2003 when the government regulatory body approved the commercialization of Bt corn. 


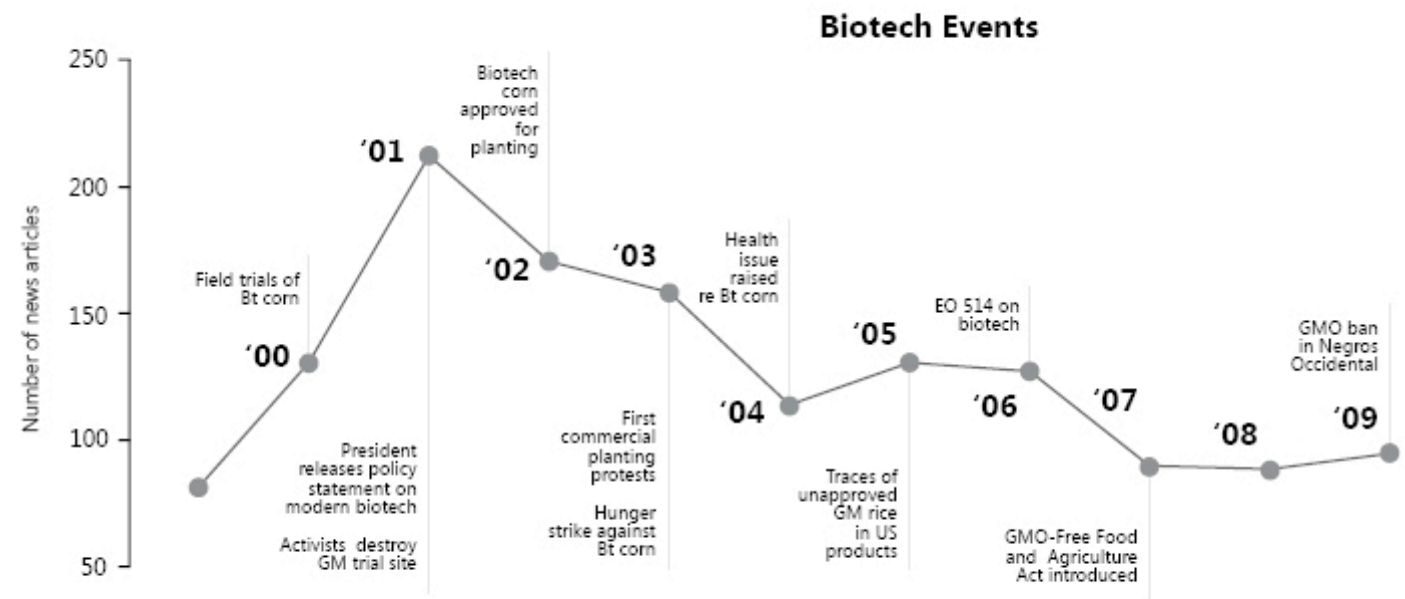

Figure 2. News coverage amidst political and biotech events, 2000-2009.

Articles experienced a sudden spike when emotion-ladened events like uprooting of field trials by environmental groups, hunger strike protesters against the technology camped in front of the Department of Agriculture, and other groups called for a moratorium or ban on the planting of biotech crops. There was a decline in articles in 2004, and a sudden spurt in 2005-2006. Number of articles eventually reached a plateau from 2007-2009, registering a monthly figure of 88-94 articles per year, down from a high of 212 in 2001. Interest in biotechnology waned or fell sharply during this period suggesting a shift in salience in coverage until such time that another episodic event will again intensify reporting.

The effect of key information milestones, represented by major political issues, was examined to see their effect on coverage and framing. During the peak periods, articles on biotechnology received adequate coverage and were able to receive attention in relation to other top stories. However, coverage was down particularly in months when potential articles had to compete with headline news such as the plunder case against a Philippine president (2001), attempted coup d'etat (2003), national elections (2004), and a government corruption case with a Chinese telecommunication project (2008). As shown in Figure 3, during a specific episode on the plunder trial in 2001, a total of 124 articles were written as against 45 biotech articles in the PS. During the attempted coup d'etat, 69 articles were published as against 36 biotech articles. The national elections generated 77 articles versus 23 biotech articles while the national broadband network controversy resulted in 122 articles with only 29 biotech articles during the same period.

Occasional spikes in media coverage did not deter from the fact that issues of agricultural biotechnology received modest attention on the overall media agenda compared to major political issues. The limited agenda status can be explained by the dominant framing of the biotech issue around social progress rather than on the political dimension that creates media interest. Media spikes, however, were often a result of 'drama' (uprooting of field trials, hunger strike, health issues of a cultural minority) forwarded by environmental groups, thus, suggesting that biotech articles tend to gravitate towards such events rather than to the science. The results validate the observation of Hoban ${ }^{23}$ that selectivity of the mass media in terms of coverage favored politics more than science. Nevertheless, it is worth noting that compared with the media coverage on agricultural biotechnology of the London Times and Washington Post from 1990 to 2001, where peak coverage was at 80 articles in $2001,{ }^{24}$ Philippine media managed to peak at 212 articles during the same time period.

About $85 \%$ of all articles were news items with opinion pieces accounting only for $8 \%$. However, of the three newspapers, PDI devoted $19 \%$ to opinion articles. Columnists could be identified in terms of their views towards the technology which remained consistent through the years. A PS columnist released 20 opinion pieces on biotech from 2004-2007 mostly classified as negative in tone. Feature articles which dealt more in detail about the technology and photo releases were few and far between. More than $40 \%$ of these feature articles were published in 2000-2002 at a time when biotechnology was a relatively new term and needed elaboration and discussion. In contrast, an analysis of 20 years of biotech coverage in U.S. papers 
found that only $4 \%$ of the articles appeared in science sections, $26 \%$ appeared as news stories, $24 \%$ were in the business section, $28 \%$ were opinion pieces, and $5 \%$ appeared on food or lifestyle pages. ${ }^{25}$

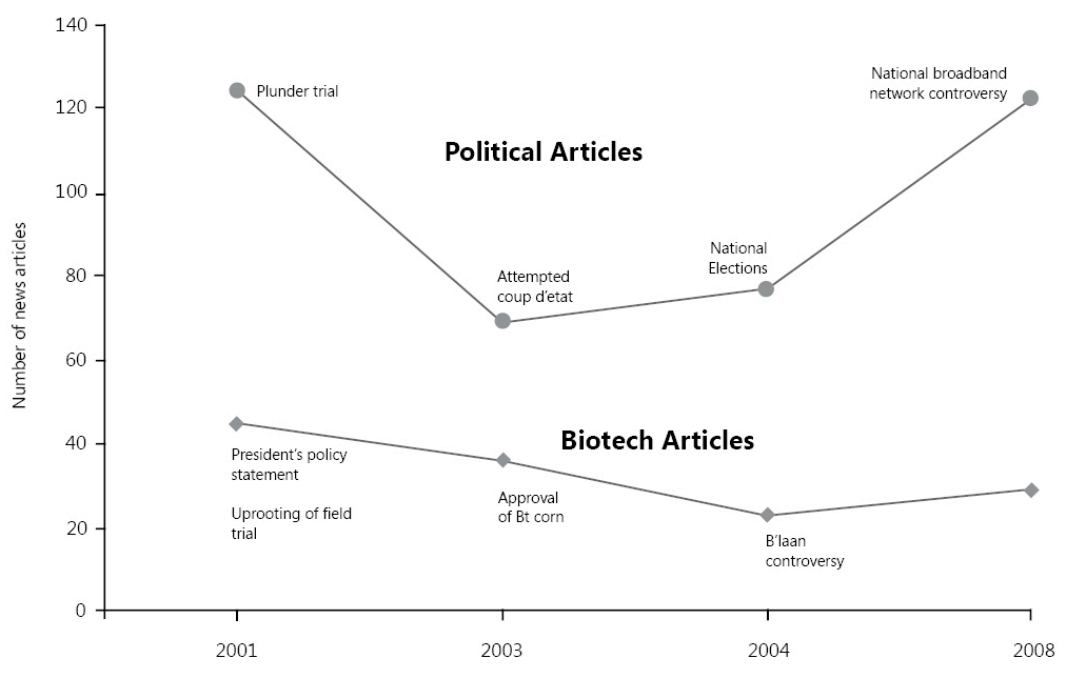

Figure 3. Comparison of number of articles generated by key political and biotech events.

Articles by Tone. Majority of the articles published by the three newspapers were positive (41.3\%) and neutral $(38.2 \%)$ in tone. Only about $19.8 \%$ were negative in stance. It is interesting to note that PS and MB had the most number of positive articles (48\% and 43\%, respectively) while PDI had more negative articles $(44 \%) . \quad M B$ is regarded as "pro-administration regardless of whoever is in power and also for its optimistic and non-sensational journalism". Its new marketing tagline is "There's good news here." which enhances its focus on positive news articles. ${ }^{26}$ PDI is known for its "Balanced News, Fearless Views" slogan while PS is described as a "feel good" newspaper. Most of the positive articles dwelt on the benefits of the technology, potential scenarios for the technology, and government and scientific support. Negative articles tend to focus on health issues such as the technology allegedly causing sickness, cancer, and even mental retardation, baldness, and homosexuality. There was no perceived change in the tone of articles over time, suggesting a positive environment for the technology in the media arena.

Sources of Articles. Most news articles are source generated or angled based on the perspective of individuals or organization of perceived credibility. Estimates put half or more of newspaper sources as source originated. ${ }^{27,28}$ It is thus important to identify the 'voices' behind the information that serve as basis for how stories are framed.

The media relied on multiple sources of information for articles they published. These were, in the order of frequency of use, government which accounted for $37 \%$, civil society $(22 \%)$, international groups $(16 \%)$, universities/R\&D institutions (14\%) and private industry companies (11\%). Figure 4 shows the sources cited by articles of the three newspapers. In contrast to heavy representation of single sources in science writing, the Philippine media strives for balance by citing multiple sources. It is also influenced by the need for newspapers to project neutrality thus crediting representatives of major institutions who in turn have the power to define key issues. When government sources, i.e., Departments of Agriculture and Science and Technology, were cited articles tend to be positive and neutral while negative articles cited environmental groups (Greenpeace, Friends of the Earth, GRAIN, Masipag (environmental group) and KMP (a farmers' alliance). MB and PS relied more on government sources for their articles (and hence a trend to have more positive to neutral news) while PDI had environmental groups as major sources for their articles, hence a tendency for articles with a negative tone. 


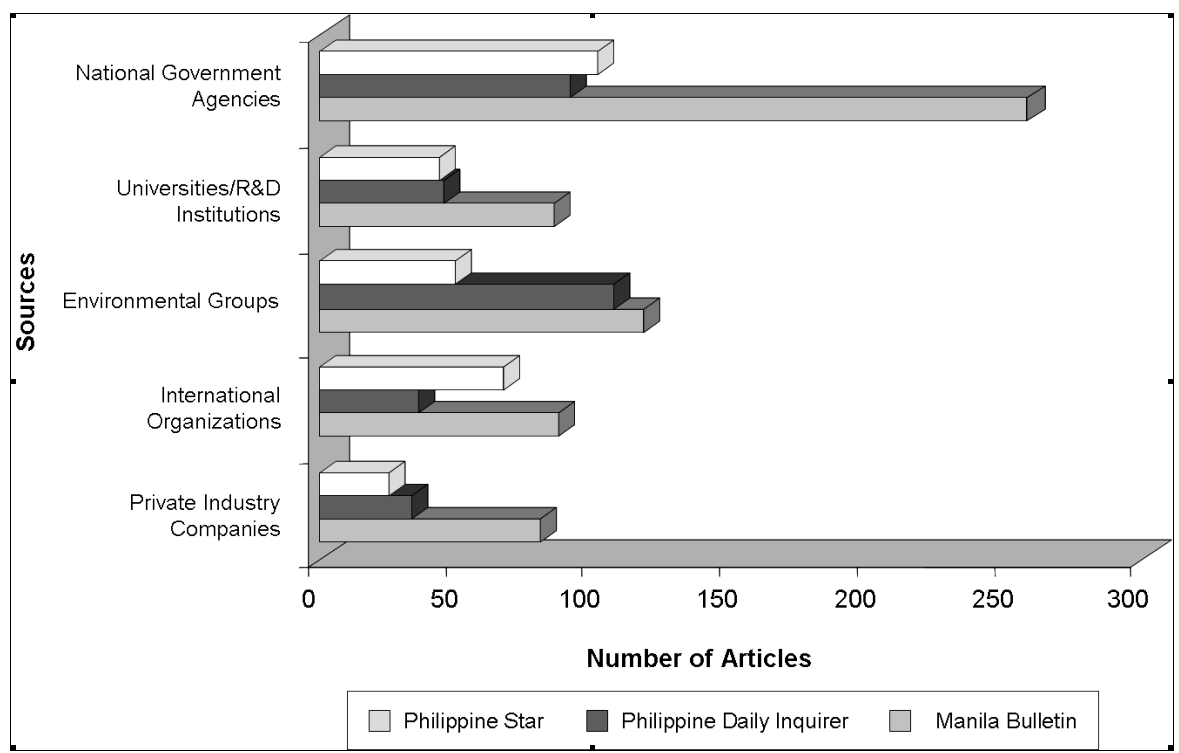

Figure 4. Sources cited by biotech articles of top three newspapers, 2000-2009.

Media Frames. Journalists use story frames that determine the importance of a topic or issue. Frames can highlight certain points of view, define perceived aspects of significance, and explain how issues should be understood. ${ }^{29}$ Articles published in 2000-2009 were categorized according to the frame used.

Among the three newspapers, the most prominent frame was public accountability or governance (Table 2). Specific focus was on government support to biotechnology, guidelines on the commercialization of $\mathrm{Bt}$ corn, regulations related to technology commercialization and labeling, responsible use of technology, and government's stand on requests by environmental groups for a moratorium or ban on planting biotech crops. These stories coincided with the period when government was actively seeking the approval of biotech commercialization in the country. There was a significant increase in the number of articles incorporating this frame between the period 2002-2003 and 2004-2005. It was during this time when the government regulatory body approved the commercialization of Bt corn.

\begin{tabular}{llllll}
\hline & $2000-2001$ & $2002-2003$ & $2004-2005$ & $2006-2007$ & $2008-2009$ \\
\hline Social Progress & 26 & 14 & 15 & 26 & 20 \\
Morality/Ethics & 11 & 9 & 8 & 3 & 7 \\
Scientific Validity & 26 & 18 & 14 & 4 & 8 \\
Public Accountability/Governance & 30 & $43 \mathrm{a}$ & $20 \mathrm{a}$ & 16 & 11 \\
New Research & 31 & 15 & 27 & 19 & 10 \\
Conflict/Strategy & 13 & 24 & 15 & 13 & 21 \\
Public Engagement & 39 & 32 & 7 & 10 & 8 \\
Others & 20 & 34 & 31 & 24 & 14 \\
\hline
\end{tabular}

Independent sample t-tests were used to identify significant mean differences ( $\mathrm{p} \leq .10)$ which are indicated by paired superscripts.

Table 2. Frames used in articles of top three newspapers, 2000-2009.

During the first four years of coverage, MB used social progress as the prominent media frame in defining agricultural biotechnology. The social progress frame featured small scale farmers benefiting from the technology in terms of higher yields, savings on pesticides use, and higher income. Other articles focused on the potential ability of transgenic crops to lift the country's agricultural competitiveness and the role of genetically modified (GM) food in helping to solve the hunger problem.

The use of social progress frame is predictable because articles are generally slanted with a business angle as MB is a business paper. However, there was an eventual shift in the use of frames. Scientific validity and conflict/strategy rose as the leading frames from which the writers discussed the technology, possibly as they relied on experts in the academe and environmental groups as sources of information (Table 3). 


\begin{tabular}{|c|c|c|c|c|c|}
\hline & $2000-2001$ & $2002-2003$ & $2004-2005$ & $2006-2007$ & $2008-2009$ \\
\hline Social Progress & $15^{\mathrm{a}}$ & $6^{\mathrm{a}}$ & 10 & 15 & 15 \\
\hline Morality/Ethics & 5 & 1 & 4 & 0 & 3 \\
\hline Scientific Validity & 12 & 9 & $11^{\mathrm{a}}$ & $2^{a}$ & 5 \\
\hline Public Accountability/Governance & 13 & 23 & 14 & 11 & 9 \\
\hline New Research & 21 & 10 & 22 & 10 & 4 \\
\hline Conflict/Strategy & 2 & 9 & $8^{a}$ & $3^{a}$ & 8 \\
\hline Public Engagement & 12 & 7 & 3 & 5 & 3 \\
\hline Others & 16 & 12 & 24 & 16 & 5 \\
\hline
\end{tabular}

Independent sample t-tests were used to identify significant mean differences $(\mathrm{p} \leq .10)$ which are indicated by paired superscripts.

Table 3. Frames used in articles by Manila Bulletin, 2000-2009.

Table 4 indicates the media frames that were used prominently by the writers of PS throughout a decade of coverage. A significant increase in the mean number of articles in the use of social progress and public engagement characterizes the prominence of these two frames during the first four years of coverage. The use of public engagement as a frame showed a noteworthy increase in the first four years of coverage. These stories highlighted personal testimonies of farmers and public sentiments. The public engagement frame did not fair well on the fifth year since the mean difference in number of articles significantly decreased.

\begin{tabular}{|c|c|c|c|c|c|}
\hline & $2000-2001$ & $2002-2003$ & $2004-2005$ & $2006-2007$ & $2008-2009$ \\
\hline Social Progress & $8^{\text {aa }}$ & $7^{\text {aa }}$ & 3 & 10 & 5 \\
\hline Morality/Ethics & 2 & 4 & 3 & 2 & 2 \\
\hline Scientific Validity & 8 & 2 & 1 & 1 & 1 \\
\hline $\begin{array}{l}\text { Public } \\
\text { Accountability/Governance }\end{array}$ & 10 & 8 & 5 & 5 & 0 \\
\hline New Research & 4 & 1 & 3 & 3 & 2 \\
\hline Conflict/Strategy & 2 & 5 & 6 & 2 & 6 \\
\hline Public Engagement & $9^{\text {aa }}$ & $15^{\mathrm{aa} / \mathrm{aaa}}$ & $2^{\text {aaa }}$ & 5 & 3 \\
\hline Others & 3 & 9 & 6 & 4 & 5 \\
\hline
\end{tabular}

Independent sample t-tests were used to identify significant mean differences $(\mathrm{p} \leq .10)$ which are indicated by paired superscripts. aa - significant at $5 \%$ level of significance

aaa- significant at $1 \%$ level of significance

Table 4. Frames used in articles by Philippine Star, 2000-2009.

The PDI articles did not have a preferred story frame and instead chose to develop their articles on a perceived area of interest over time (Table 5).

\begin{tabular}{lccccc}
\hline & $2000-2001$ & $2002-2003$ & $2004-2005$ & $2006-2007$ & $2008-2009$ \\
\hline Social Progress & 3 & 2 & 2 & 1 & 0 \\
Morality/Ethics & 5 & 4 & 1 & 2 & 2 \\
Scientific Validity & 6 & 8 & 2 & 2 & 2 \\
Public Accountability/Governance & 8 & 12 & 2 & 7 & 8 \\
New Research & 7 & 4 & 1 & 1 & 7 \\
Conflict/Strategy & 9 & 10 & 2 & 2 & 5 \\
Public Engagement & 18 & 10 & 1 & 5 \\
Others & 2 & 14 & 3 & 5 \\
\hline
\end{tabular}

Independent sample t-tests were used to identify significant mean differences $(\mathrm{p} \leq .10)$ which are indicated by paired superscripts.

Table 5. Frames used in articles by Philippine Daily Inquirer, 2000-2009.

Defining biotechnology/Crafting messages. It is presumed that choice of terms influences how audiences respond to biotech stories. Journalists preferred to use the word GM or GMO and or biotechnology almost $75 \%$ of the time followed by the word genetically engineered. The same finding was observed among a survey of U.S. reporters. ${ }^{30}$ In declining order of use were the words transgenic, genetically altered, genetically improved, and genetically enhanced. Eighty-four percent of all articles 
used the words biotechnology/GM but did not define the words anywhere in the text. Writers assumed that biotechnology/GM were common and widely known terms that did not need elaboration or definition. Only 76 of 1,355 articles provided a scientific explanation of the term (where biotechnology is defined as "... any technology that use living organisms or their components to produce or modify products, or to enhance or improve other living organisms.").

Textual imagery was used by environmental groups and opinion writers to popularize the technology to a non-technical audience. Fear appeal is notable in the early years of media coverage as exemplified by exaggerated claims, i.e., "millions of dead bodies and sick children, physical deformities, and disease clusters that could allegedly rise from the application of biotechnology to agriculture and the use of genetically modified raw materials in the manufacture of food products".31

Those on the side of biotechnology however, who attempted to popularize the term also made their own exaggerated claims, referring to biotechnology as "the next gold mine", "a silver bullet," "most promising option," "salvation of the poor", "quick fix for a global problem," "manna from heaven," "an achievement that could throw open the gates to a new green revolution of super crops", "the millennium's menu against a million enemies", and "solution to food production problems".

As soon as a commercial product of biotechnology was available in the Philippines, media coverage peaks where articles were negative tended to shift from using emotional imagery to focusing on real time events exemplified by hunger strikers in 2002, and the blood contamination issues of a tribal community allegedly exposed to Bt corn pollen in 2004. Positive articles saw a trend to use less exaggerated phrases and to talk about the technology as contributing to solving the food problem rather than as the sole solution. This is exemplified by an MB article that said biotechnology could "help agricultural communities increase their production, improve their incomes and provide consumers with nutritious and disease resistant food products", 32

\section{Conclusions}

The Philippines is a typical developing country that is still agriculture-based with farming and related activities as means of livelihood for about $70 \%$ of its populace. Despite being a relatively small player in the biotech arena, it is ranked number 11 among the mega-countries in the world growing at least 50,000 hectares of biotech crop and remains to be the only country in Asia that is growing biotech corn in commercial quantity.

Media coverage may be a contributing factor to the generally favorable perception of the technology in the country despite occasional sensational write-ups on the technology fueled by event-centered or episodic happenings that generate story interest. Consumer knowledge on the topic is based mostly on media as a source of information and while their exposure to sources was low, given the chance to access information, stakeholders preferred mass media. ${ }^{33,34}$ During a decade of biotech journalism, the Philippine media showed maturity in its reporting over time. This was shown by the trend towards positive to neutral stories, preference for institutional sources of information, and a shift from sensational to balanced coverage.

Media coverage in the Philippines is dominated by stories about politics and entertainment. Although biotechnology news was not high in the media agenda as compared to political events, coverage was sustained and had occasional peaks that helped bring attention to and or generate interest on the topic. Despite this however, peak coverage of events may be the only time when the public gets to know about the topic and the possibility for them to seek additional information.

Timing was a crucial variable in media coverage. There were spikes in press attention but often, issues received only modest attention. Political highlights such as a former President being put on trial for plunder and eventually jailed and a subsequent call for presidential elections placed biotech news on the back burner. Emotional or dramatic coverage of events such as uprooting of field trials, hunger strikes, and alleged health problems faced by cultural minority in contact with Bt corn pollen triggered media and public attention. Eventually, however, dramatic elements would be exhausted and not enough to sustain interest. The inherent drama and controversy in these issues that triggered a substantial share of the limelight but not dramatically long enough to be reported regularly. ${ }^{35}$ Results are also consistent with other studies ${ }^{36}$ that even at its peak levels of attention, biotechnology is not at the top of the media's agenda in comparison with other major news items. News articles hardly merited front page coverage, with majority placed in specific sections such as agriculture, science and technology, and business, but more in the latter because articles 
were slanted to potential business opportunities to merit newspaper space and editorial approval. The Philippine press wrote mostly news articles, similar to findings in the U.S. and Great Britain although the latter published a higher number of editorials than the U.S. on agri-biotech.

A core of science writers do exist, they are identifiable, actively seek information about the technology from credible sources, and continue to monitor the biotech scene. In 2004, national awards were given to the best articles in biotechnology through the Jose G. Burgos Awards for Biotechnology, named after a known press freedom advocate. The award was established to "encourage journalists to push the frontiers of scientific inquiry". ${ }^{37}$ This development augers well for a developing country as biotechnology is not merely considered as just a topic to write about but a topic of value and relevance.

The use of government as a major source of information indicates the level of trust and credibility placed on it. The trend in Philippine media coverage is that it is generally pro-biotechnology and dominated by government sources. This is in contrast to the lack of institutional trust by European stakeholders largely blamed on their perception of government's inability to respond to outbreaks like mad cow disease. ${ }^{38}$ Losing trust in this instance had far-reaching consequences such that people become cynical about their government's ability to regulate a new technology. Hence, perception of benefits more than risks are higher when trust is equally high.

Yet it is important to note that environmental groups are also considered key information sources and in many instances have provided media opportunities to focus on certain biotech issues and concerns. Local nongovernment organizations are performing a role as alternative science communicators in the social conflict concerning agricultural biotechnology. In particular this means framing scientific and technological developments as social issues which allow conflicting issues to be raised and debated on. Media's role is thus to be a facilitator of public discussion and (science) democratization. ${ }^{38}$

The articles' trend to be positive and neutral is also a positive sign as it shows that journalists are taking time to present sides of an issue giving readers enough facts and information to make their own decision about the technology. Balanced reporting indicates a level of neutrality with journalists deliberately not taking sides on the issue and including various information sources to validate claims and counterclaims. Yet on the other hand, negative articles defined biotechnology by textual imagery that added meanings and symbolic attributions. Use of textual imagery rather than rational arguments enabled writers to create and evoke emotions and reduce difficulty in comprehending what is otherwise a difficult subject yet only led to further misinformation and misunderstanding.

The evolution in definitions of terms such as biotechnology highlights how words gain meaning and become part of the consciousness in the minds of readers. That biotechnology is no longer defined in articles suggests that it is already considered part of journalists' terminology and subsequently, that of the public.

An understanding of the use of frames helps in providing meaning or interpretation of events from the perspective of a journalist. Single issue events have to compete with many others and how an issue is framed to attract attention through story angles determine how the public should in turn understand the technology. The dominant frame used was public accountability of governance which reflects high regard for government pronouncements. In contrast, U.S. and European media had very low use of this frame preferring scientific progress as a way to discuss biotech. ${ }^{39,40,41}$ This is to be expected as the U.S. has had more technological breakthroughs than the Philippines.

The fear appeal, through questions about health risks and to a less extend social and moral consequences of the technology, continues to be used through the years by activists. This scenario has upgraded biotechnology to a social phenomenon rendering it more of a social issue than a technological development. ${ }^{41}$ The polarity of views is what keeps the debate alive and allows issues to be addressed. It is important therefore to keep the debate at a level that does not leave the public more confused than informed, and to allow discussion to be focused on facts rather than on normative arguments. ${ }^{42}$ Biotechnology is thus an ongoing dramaturgy "where the end is not yet defined, but where many actors are working on the plot for different audiences". 43

Overall, the Philippine case study provides a study of mass media in a developing country and how it responds to emerging technologies such as biotechnology. It should ignite interest among other developing countries particularly those countries that have adopted biotech crops to appreciate the role of mass media in increasing awareness and public understanding of biotechnology. The debate enabled a complex and contentious topic to be integrated into the mainstream of news reporting, and eventually evolved from an emotional discourse to one that allows an informed discussion. 
It is thus important to understand how media works - the frames that media use to communicate issues, the sources they use which influence how stories are framed, and the amount of space allotted to science topics, among others - so that organizations are able to develop a plan that allows them maximum coverage. With opinions being formed on the basis of little information, the role of newspapers is crucial in the communication of science.

\section{Notes and references}

1 I. Dalmacio (2008), Initiatives and Perspectives of the Philippine Department of Science and Technology, in Straight Talk on Biotechnology vol. 1, B. Peczon and A. Manalo (eds), Ateneo de Manila University Press, Manila Philippines, p. 69-75.

2 C. James (2009), Global Status of Commercialized Biotech/GM Crops: 2009, ISAAA Brief No. 41, ISAAA, Ithaca, New York, p. $138-143$.

3 D. Brossard and M. Nisbet (2006), Deference to scientific authority among a low information public: Understanding U.S. opinion on agricultural biotechnology, International Journal of Public Opinion Research. 19(1): 24-52.

4 C. De Vreese (2005), News framing: Theory and typology, Information Design Journal + Document Design 13(1): 51-62, John Benjamins Publishing Co., Amsterdam, Netherlands.

5 S.H. Priest (2001), A Grain of Truth: the Media, the Public and Biotechnology, Rowman and Littlefield Pub., Inc. Maryland, U.S.A.

6 L.A. Marks, Leonie and N. Kalaitzandonakes (2003), Mass Media Communications About Agrobiotechnology, AgBioForum 4(3\&4): 199-208, retrieved March 11, 2010; available at: http://www.agbioforum.org/v4n34/v4n34a08-marks.htm.

7 D. Brossard, J. Shanahan and T.C. Nesbitt. eds. (2007), The Public, the Media and Agricultural Biotechnology, CAB International, Wallingford, Oxon U.K., p. 405.

8 M. Nisbet and B.V. Lewinstein (2002). Biotechnology and the American public: The policy process and the elite press, 1970 to 1999, Science Communication 23(4): 359-391.

9 L.A. Marks, N. Kalaitzandonakes, L. Wilkins and L. Zakharova (2007), Mass media framing of biotechnology news, Public Understanding of Science 16(2): 183-203, retrieved March 11, 2010; available at: http://pus.sagepub.com/content/16/2/183.full.pdf+html.

10 M. Bauer et al. (2001), The Dramatization of Biotechnology in Elite Mass Media, Biotechnology 1996-2000: The Years of Controversy, Science Museum, London U.K., p.1-18.

11 Priest, S.H, op. cit. pdf

12 M. Schaefer (2010), Taking Stock: A Meta-analysis of Studies on the Media's Coverage of Science. Public Understanding of Science, Sage Publications. Retrieved March 18, 2010; available at http://pus.sagepub.com.pdf.

13 M. Quiamo (2006), Biotechnology in the eyes of the Filipino: A synthesis of researchers on public perceptions of biotechnology, International Service for the Acquisition of Agri-biotech Applications (ISAAA), Los Banos, Laguna, Philippines, p. 102.

14 N. Juanillo Jr. (2003), The Social and Cultural Dimension of Agricultural Biotechnology in the Philippines: Public Understanding, Perceptions, and Attitudes Towards Biotechnology, University of Illinois at Urbana-Champaign and the International Service for the Acquisition of Agri-biotech Applications (ISAAA), p. 95.

15 C. Torres et al. (2006), Public Understanding and Perception and Attitude Towards Agricultural Biotechnology in the Philippines, College of Development Communication, University of the Philippines Los Banos, College, Laguna, Philippines, Southeast Asian Regional Center for Graduate Study and Research in Agriculture (SEARCA), Philippines, and International Service for the Acquisition of Agri-biotech Applications (ISAAA), p. 106.

16 M. Chong et al.(2004), Elite Asian Newspapers Coverage of Agricultural Biotechnology (1998-2002), Paper presented at the annual meeting of the International Communication Association, New Orleans, LA, retrieved March 15, 2010; available at: http://www.allacademic.com/one/www/research/index.php?click key=1.

17 M. Navarro and M. Villena (2004), Media Monitoring of Agri-Biotechnology in the Philippines: Understanding the Biotech Debate, The Philippine Agricultural Scientist 8(4): 439-451, University of the Philippines Los Banos, College, Laguna, Philippines.

18 Nielsen survey shows Inquirer is top newspaper, retrieved August 5, 2010; available at: http://www.inquirer.net.

19 M. Bauer et al., op. cit., p. 7.

20 M. Liakopoulos (2002), Pandora's Box or Panacea? Using Metaphors to Create the Public Representations of Biotechnology, Public Understanding of Science 11(1): 5-32, Institute of Physics Publishing, Bristol, United Kingdom.

21 M. Nisbet (2009), Framing Science: A New Paradigm in Public Engagement, in L. Kahlor and P. Stout (eds), Communicating Science: New Agendas in Communication, Taylor and Francis, New York U.S.A.

22 I. Banerjee and S. Logan (eds) (2008) Asian Communication Handbook 2008. AMIC Asian Communication Series. Asian Media Information and Communication Centre, Singapore. P. 405-516

23 TJ. Hoban (1995) The construction of food biotechnology as a social issue. In: Eating Agendas: Food Nutrition as Social Problems. Maurer D, Sobal J. de Gruyter A. Hawthorne, New York. p. 189-209.

24 L.A. Marks et al op.cit. 195-197.

25 L. Stenier and N. Bird (2008). Reporters See Indifference on Genetically Modified Food. Newspaper Research Journal (Winter 2008) 29(1): 63-76.

26 Manila Bulletin, retrieved August 5, 2010; available at: http://en.wikipedia.org/wiki/Manila_Bulletin.

27 N. Nisbet and B.V. Lewenstein, op. cit., p. 266

28 S.H. Priest, op. cit., pdf.

29 L.A. Marks et al., op cit., p. 183-203

30 L. Stenier and N. Bird op. cit p. 63-76. 
Manila Bulletin (2002), Government Biotech Policy Draws Support but Greenpeace Steps Up Campaign, July 4, 2002

Manila Bulletin (2005), Biotechnology: Solving National Hunger, January 2, 2005.

N. Juanillo Jr., op. cit., p. 36

C. Torres et al., op. cit., p. 29-42

N. Nisbet and B.V. Lewinstein, op. cit., p.382-383 .

6 L. Lundy and T. Irani (2004), Framing biotechnology: A comparison of U.S. and British national newspapers. Journal of Applied Commmunications 88(2): 37-49.

37 L. Fernandez (2008), Biotech Yearbook, Special Issue of BioLife Magazine, Biotechnology Coalition of the Philippines and J. Burgos Media Services, Inc., Quezon City, Philippines, p. 41-43.

38 D. Brossard and J. Shanahan (2007), Perspectives on communication about agricultural biotechnology. The Public, the Media and Agricultural Biotechnology, D. Brossard, J. Shanahan and T.C. Nesbitt (eds). CAB International U.K., p. 3-20

39 P. Maeseele (2009), NGOs and GMOs: A Case Study in Alternative Science Communication, Javnost - The Public 16(4): 55-72.

40 L. Lundy and T. Irani, op. cit, p. 45.

$41 \quad$ N. Nisbet and B.V. Lewinstein, op. cit., p.382-383.

$42 \quad$ L.S. Marks et al. op. cit. p. 194.

43 M. Liakopoulos, op. cit., p. 12-13.

44 J. Kolodinsky (2007), Biotechnology and Consumer Information, in D. Brossard, J. Shanahan, and T.C. Nesbitt (eds), The Public, the Media and Agricultural Biotechnology, CAB International, Wallingford, Oxon U.K., p. 161-178.

45 M. Bauer et al., op. cit., p. 17

\section{Authors}

Mariechel J. Navarro is manager of the Global Knowledge Center on Crop Biotechnology, a program of the International Service for the Acquisition of Agri-biotech Applications (ISAAA) Southeast Asia Office, Los Banos, Laguna, Philippines. She coordinates a network of Biotechnology Information Centers in Africa, Asia, Europe, and Latin America. In addition, she is editor of the weekly e-newsletter Crop Biotech Update sent to over a million subscribers all over the world. E-mail: m.navarro@isaaa.org.

Jenny Panopio is Network Administrator of the Southeast Asian Regional Center for Graduate Study and Research in Agriculture (SEARCA) Biotechnology Information Center based in the Philippines.

E-mail: jap@agri.searca.org.

Donna Bae Malayang and Noel Amano, Jr. are research assistants based at ISAAA.

E-mail: dbmalayang@gmail.com,noel.amano.jr@gmail.com.

How TO CITE: M.J. Navarro, J.A. Panopio, D.B. Malayang and N. Amano Jr., Print media reportage of agricultural biotechnology in the Philippines: a decade's (2000-2009) analysis of news coverage and framing, Jcom 10(03) (2011) A01. 